\section{Kadonnutta moraalin suuntaa etsimässä}

Kenan Malik (2016). Moraalin suuntaa etsimässä. Etiikan maailmanhistoria (The Quest for a Moral Compass 2014). Suom. Tapani Kilpeläinen. Tampere: niin \& näin. 473 sivua. ISBN 978-952-7189-06-1

INTIALAISSYNTYINEN, Britanniassa asuva Kenan Malik (1960-) kertoo tarinan moraalikompassin etsinnästä ja kulkee samalla tarinansa virrassa ymmärtääkseen, mitä moraali on ja miten se elämäämme sopii. Neurobiologiaa ja tieteiden historiaa opiskellut Malik on aiemmin työssään suuntautunut biologian filosofiaan sekä monikulttuurisuus-, moninaisuus- ja rotuteorioihin. Hän on kirjoittanut teokset The Meaning of Race (1996), Man, Beast and Zombie (2000) ja Strange Fruit: Why Both Sides Are Wrong in the Race Debate (2008).

Malik perustelee moraalin historiankirjoituksen tarvetta sillä, että ymmärrys siitä, mitä on olla ihminen tai mitä ihminen voisi olla, on aikojen saatossa monesti muuttunut. Moraalin historian käännekohdat ovat samalla yhteiskunnallisen muutoksen ratkaisevia hetkiä. Ne myös muuttavat tarinaa siitä, miten ihmisenä oloa kulloinkin ymmärrämme.

Kirjan esitystapa on lukijaystävällinen, vaikka mutkia ei turhan päiten suoristeta. Teos imaisee lukijan mukaansa dekkarin tavoin, vaikka lopussa syyllinen ei paljastukaan. Ansiokasta on, että 'maailmanhistoria' ei teoksessa tarkoita vain länsieurooppalaista ja pohjoisamerikkalaista historiaa kuten monesti on tapana. Toinen ansio on moni- tieteisyys, ja kolmas on kirjoittajan kyky ja rohkeus esittää ikään kuin ohimennen ja varoittamatta päätelmiä, joissa kiteytyy huikeita, etten sanoisi huimausta aiheuttavia historiallisia kehityslinjoja. Historioitsijat ja filosofit voivat olla Malikin päätelmistä ja tiivistyksistä montaa mieltä, mutta ainakin hän perustelee väitteensä ymmärrettävästi.

\section{MORAALIN TARINA}

Malikin tarina alkaa perinteisesti antiikin Kreikasta, jossa moraali hänen mukaansa auttoi panemaan ennakoimattoman järjestykseen. Ilias on moraalikertomus, mutta sen moraali tuntuu vieraalta. Agamemnonin raivo ja Akilleen ylpeys eivät kuvaa heidän sisäistä maailmaansa vaan heidän käyttäytymistään ja heidän kohtalostaan päättävien jumalten toimia. Iliaasta ja Odysseiasta puuttuu 'sisäisen elämän' käsite siten kuin me sen ymmärrämme, ja sisäinen elämä projisoituu ihmisten maailmasta taistelevien jumalten näyttämöksi.

Ajan oloon sisäisestä maailmasta tulee yhä läpinäkyvämpi, mutta jumalten maailmasta läpinäkymättömämpi. Kuudennelta vuosisadalta ennen ajanlaskun alkua sankarien maailma niin Kreikassa kuin Kiinassa ja Intiassa väistyy paikalleen

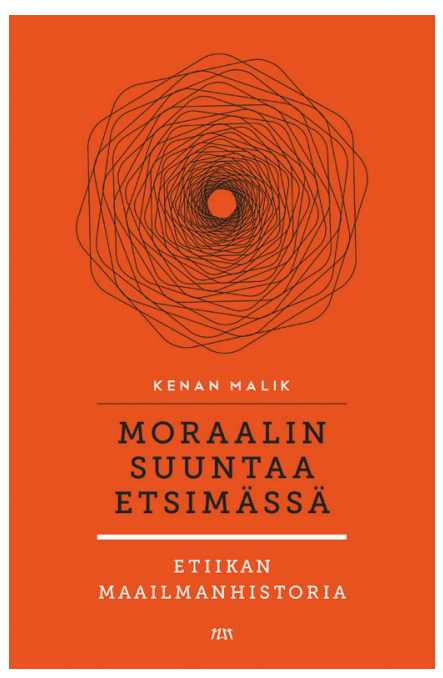

asettuneiden, yhä tuottavampien ja kekseliäämpien yhteiskuntien tieltä. Lisäksi Persiassa ja Palestiinassa valetaan uudenlaisia filosofioita, uskontoja ja moraaliajatuksia.

Jotkut ajattelijat eri puolilla maailmaa alkavat puhua ihmisen rationaalisuudesta, ja ihmisen arvokkuuden ajatus saa uusia merkityksiä. Kolme suurta monoteistista uskontoa kehittyvät yhteiskunnan murroskausina. On syytä olla moraalinen, koska kaikkinäkevä, kaikkitietävä ja kaukaa viisas jumala vaatii sitä.

Modernin maailman aamunkoitteessa, 1500-luvulta lähtien ajatus järjestä uskon palvelijana menettää Malikin mukaan uskottavuuttaan. Perinteisiä yhteisöjä hajoaa, eivätkä yhteiskuntien rakenteet ole enää valmiiksi annettuja, vaan niistä aletaan kiistellä. Yksilöiden, ainakin joidenkin yksilöiden, autonomiasta tulee aiempaa tärkeämpää. Valistuksen myötä poliittinen ja moraalinen keskustelu laajenee pieneltä eliitiltä laajoille piireille. 
MORAALIARVOJEN

SUBJEKTIIVISUUS JA

OBJEKTIIVISUUS

Moraalikeskustelu on antiikista asti usein kaksinapaistunut kiistaan moraalin subjektiivisuudesta tai objektiivisuudesta. Kiistan toinen osapuoli sanoo, että moraali on vain subjektiivisen maun tuotetta ja yksilöllisiä mieltymyksiä. Vastakkaista kantaa edustava puolestaan yrittää kiinnittää moraaliväitteet ja -arvot milloin jumaliin ja tuonpuoleiseen, milloin tieteeseen.

Vaikka moraalikysymyksiin ei voi olla samalla tavoin objektiivisia vastauksia kuin luonnontieteen kysymyksiin, ne eivät Malikin mukaan ole pelkkää subjektiivisen halun tai maun ilmausta. Moraalin vastaukset voivat olla rationaalisia ja juurtuneita yhteiskunnallisista tarpeista syntyneeseen rationaalisuuteen.

Väitteensä tueksi moraalin yhteiskunnallisesta rationaalisuudesta Malik olisi hyvin voinut mainita sosiologian isähahmon Émile Durkheimin (1858-1917), jonka ajattelussa moraaliset normit toimivat yksilöllisten intressien vastavoimana ja estävät yhteiskunnan hajoamisen.

Sen sijaan kirjassa tukeudutaan skotlantilaiseen moraali- filosofiin Alasdair McIntyreen (1929-), jonka mukaan yksilön kertomus on aina osana yhteisön kertomusta, ja yhteinen etsintä kertomusten avulla tekee moraaliväitteistä enemmän kuin subjektiivisia. Voin tietää, mitä minun tulee kulloinkin tehdä, vasta kun tiedän, millaisiin yhteisöni kertomuksiin kuulun. Moraalisten vastausten etsintä muotoutuu sekä henkilökohtaisesta että yhteisön hyvästä.

Oudoksuntaa voi herättää kirjoittajan tulkinta moraalin historiasta paljolti rationaalisuuden historiana. Toinen on ensimmäinen -ajattelustaan tunnettua Emmanuel Levinasia (1906-1995) ei mainita edes ohimennen.

\section{LOHDUTUS \\ NUORALLAKÄVELIJÄLLE}

Jos enemmistö pitäisi totuudellisuutta pahana ja kidutusta hyvänä, kaikkien elämä vahingoittuisi perustavasti, Malik päättelee. Jotta järki saataisiin koskettamaan sosiaalisia suhteita, määrittelemään rationaalisia vastauksia moraalisiin kysymyksiin, tarvitaan sosiaalista sitoutumista ja kollektiivista toimintaa. Historian ja nykyhetken pitkät varjot kuitenkin muistuttavat siitä, ettei rationaalisuus suinkaan etene suoraviivaisesti.
Auschwitzista selvinnyt logoterapian perustaja Viktor Frankl (1905-1997) pohtii yksilöiden kykyä selvitä äärimmäisistä kauhuista:

"Ihmisen ei loppujen lopuksi tulisi kysyä, mikä on hänen elämänsä tarkoitus, vaan päinvastoin hänen täytyy todeta, että juuri häneltä kysytään”.

Malik katsoo, että Franklin ymmärrys ihmisistä arvon luojina ja merkityksen tekijöinä soveltuu myös ihmisiin kollektiivina. Löydämme yksilöllisyytemme ainoastaan muiden välityksellä, ja vain muiden kautta opimme ymmärtämään arvojen merkityksen ja merkitysten arvon.

Aiemmin haettiin ja saatiin lohdutusta ajatuksesta, että moraalikartta on jo piirretty ja määritelty, ja tarvitsemme enää kompassin käytön taitoa, valmiiksi määritellyn hyväksymistä tai hylkäämistä. Tämä varmuus suojaa vastuulta ja kauhulta, joita todellisiin moraalivalintoihin väistämättä kuuluu. Nykyisin sitä vastoin tarvitsemme Malikin mukaan lohdutusta, koska olemme menettäneet uskon kykyymme piirtää moraalin kartta. Ihmiset ovat tuomittuja moraaliseen nuorallakävelyyn ilman turvaverkkoja.

\section{JUSSI ONNISMAA}

FT, dosentti, työnohjaajakouluttaja Werka kehitys Oy 